Archived version from NCDOCKS Institutional Repository http://libres.uncg.edu/ir/asu/

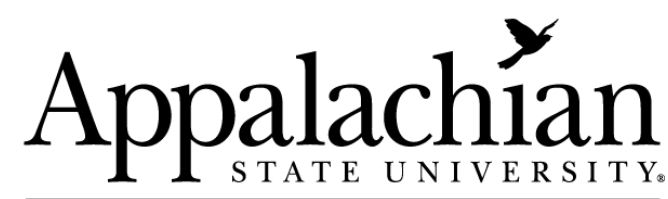

B O O N E, NORT H C A R O L I A

\section{Fostering Tourism And Entrepreneurship In Fringe Communities: Unpacking Stakeholder Perceptions Towards Entrepreneurial Climate}

\author{
By: Carol Kline, Lauren Duffy, and Dana Clark
}

\begin{abstract}
The success of entrepreneurial ventures in tourism is tied to the community ecosystem that supports it. As such, communities are continuing to assess their entrepreneurial climate to identify areas where new programs might enhance entrepreneurial success. Based on previous measures of entrepreneurial climate, the current study furthers the entrepreneurial ecosystem literature within the context of fringe communities as it relates to tourism development. Fringe communities, which are found in the peri-urban outskirts of major cities, have increasingly grown as the urban-rural divide continues to blur. Amenity migrants flock to these communities with access to "best of both worlds" with regard to having access to the resources available in both areas. Given the complexity of community demographics emerging in these communities, this study explored whether stakeholder demographics and relationship with the community affects perception of the entrepreneurial climate. Specifically, this research examined residents' perceptions in a location demonstrative of fringe communities: Moore County, North Carolina, US. The study found that the most differing views were held on Basic Community Needs, Community spaces/green spaces, Innovative, supportive \& celebratory environment, and Community spirit.
\end{abstract}

Kline, C., Duffy, L., \& Clark, D. (2018). Fostering tourism and entrepreneurship in fringe communities: Unpacking stakeholder perceptions towards entrepreneurial climate. Tourism and Hospitality Research. https://doi.org/10.1177/1467358418781443. Publisher version of record available at: https://journals.sagepub.com/doi/full/10.1177/1467358418781443 


\title{
Fostering tourism and entrepreneurship in fringe communities: Unpacking stakeholder perceptions towards entrepreneurial climate
}

\author{
Carol Kline \\ Hospitality and Tourism Management, Walker College of Business, Appalachian State \\ University, NC, USA
}

\section{Lauren Duffy}

Department of Parks, Recreation, and Tourism Management, College of Behavioral, Social, and Health Sciences, Clemson University, SC, USA

\section{Dana Clark}

Hospitality and Tourism Management, Walker College of Business, Appalachian State University, NC, USA

\begin{abstract}
The success of entrepreneurial ventures in tourism is tied to the community ecosystem that supports it. As such, communities are continuing to assess their entrepreneurial climate to identify areas where new programs might enhance entrepreneurial success. Based on previous measures of entrepreneurial climate, the current study furthers the entrepreneurial ecosystem literature within the context of fringe communities as it relates to tourism development. Fringe communities, which are found in the peri-urban outskirts of major cities, have increasingly grown as the urban-rural divide continues to blur. Amenity migrants flock to these communities with access to "best of both worlds" with regard to having access to the resources available in both areas. Given the complexity of community demographics emerging in these communities, this study explored whether stakeholder demographics and relationship with the community affects perception of the entrepreneurial climate. Specifically, this research examined residents' perceptions in a location demonstrative of fringe communities: Moore County, North Carolina, US. The study found that the most differing views were held on Basic Community Needs, Community spaces/green spaces, Innovative, supportive \& celebratory environment, and Community spirit.
\end{abstract}

\section{Keywords}

Fringe community, counter-urbanization, entrepreneurial ecosystem, entrepreneurial climate

\section{Introduction}

Recently, the notion of the entrepreneurial ecosystem has emerged as a framework to evaluate support for entrepreneurial activity with regard to environmental elements that facilitate or constrain entrepreneurship in a given area (Autio et al., 2014; Isenberg, 2011). Entrepreneurship is often considered a phenomenon of urban centers that innately have healthy competition, access to resources, and conducive population factors (Freire-Gibb and Nielsen, 2014), but given the tourism industry's unique ability to develop in rural communities where other traditional industries have declined, research on entrepreneurial conditions (i.e. entrepreneurial climate, e-climate) in rural areas

\section{Corresponding author:}

Dana Clark, Hospitality and Tourism Management, Walker College of Business, Appalachian State University, 4076 Peacock Hall, Boone, NC 28608, USA.

Email: clarkjddappstate.edu 
is well-developed (Kline and Milburn, 2010; Kline et al., 2014b; Koh, 2002; Komppula, 2014; McGehee and Kline, 2008; Wilson et al., 2001). In spite of this, there has been little focus on entrepreneurial ecosystems in fringe communities. Also called exurbia, the peri-urban, the rurban, or the urban-rural fringe, fringe communities are characteristically and geographically situated between the dichotomy of places defined as either rural or urban. Related to counter-urbanization trends, urbanization (e.g. urban sprawl), and the complexities of shifting postindustrial landscapes (Frisvoll, 2012; Halfacree, 2012), the current study contributes to the paucity of tourism research conducted on fringe communities in the US.

Drawing on literature that has investigated sociodemographic and community relationship variables that influence perceptions of entrepreneurship (Benneworth, 2004; Bosworth and Farrell, 2011; Kline et al., 2012), as well as the limited work on perceptions of tourism in fringe communities (Weaver and Lawton, 2001, 2004, 2008; Zhang, 2008), this study sought to provide clarity to the complex relationships stakeholders have to the community and the diversity of the stakeholders themselves in connection to their perceptions of the entrepreneurial ecosystem. Specifically, this research asks:

1. Does stakeholder affiliation or relationship with a fringe community (i.e. residential status, work status in the community, residential setting, and residential tenure) influence perceptions towards the entrepreneurial ecosystem?

2. Are there differences based on stakeholder sociodemographic variables including gender, race, employment sector, income, age/generation, and education, and their perceptions towards the entrepreneurial ecosystem?

3. Are there differences in perception towards entrepreneurial climate based on their self-rating of entrepreneurship?

The importance of this cannot be understated: fringe communities are varied in the sociodemographic composition of its people who also have varied and complex relationships with the community and understanding the relationship of individuals to the community is important to consider when examining perceptions towards the entrepreneurial ecosystem. In recognizing this, it is essential to understand who become the 'change-agents' (i.e. the entrepreneurs) and the context that influences the direction of future development in the community. Thus, this study investigates differences in stakeholder perceptions towards the entrepreneurial ecosystem and the conditions that support entrepreneurial efforts.

\section{Literature review}

Fringe communities. With continued trends of counter-urbanization and urbanization (Frisvoll, 2012; Halfacree, 2012), many have recognized the fallacy of the rural-urban divide construct, moving towards a continuum of peri-urbanization (Champion and Hugo, 2004). In this space between are communities -fringe communities - that are characterized by both a more diverse population of residents, as well as features of the urban built landscapes (e.g. buildings, architecture, entertainment value), and of the rural, natural landscapes (e.g. outdoor space, pastoral settings, lakes, mountains; Chase, 2015; Taylor, 2011).

Defining features of peri-urban fringe communities are their continuous rapid change, fragmentation, and growth (Chase, 2015; Koster et al., 2010; Walker and Fortmann, 2003). Formerly dichotomized as rural communities, these are communities that transform into commuter communities and communities of second-home development for retirees located on the outskirts of metropolitan areas are common examples of fringe communities, where residents may work in urban areas or utilize urban amenities, but want to live in a community that embodies that of a "small town life" in the countryside (Koster et al., 2010; Timothy, 2005). Other markers of fringe communities include business parks and industrial development zones, gated residential communities, regional airports, as well as tourism-specific operations and businesses such as theme parks and allied attractions, tourist shopping villages, modified nature-based tourism, peri-urban parks, factory outlet malls, and golf courses (Timothy, 2005; Weaver, 2005). Many growing fringe communities have a wealth of natural and cultural resources and amenities which are part of the draw for new residents. Those who are drawn to amenityrich areas are also referred to as amenity migrants or those who are seeking to live in a place that supports a particular lifestyle (Gosnell and Abrams, 2009; Pavelka and Draper, 2015). Consequently, those who are able to migrate towards desired amenities, also share other characteristics such as being older, wealthier, and more educated-often a drastic distinction from the local population (Gosnell and Abrams, 2009). Thus, amenity migration has been identified as a primary contributor of rural gentrification and the "amenitization of rural places" (Butt and Fish, 2016).

This notion also highlights the complicated relationship that many fringe communities may also have with tourism development: these natural and cultural resources that draw in new residents, also draw in 
tourists, visitors and excursionists, and in effect, become center for a new tourism and recreation economy (Koster et al., 2010). Past research has examined resident perceptions and attitude towards tourism development in fringe communities. For instance, Weaver and Lawton (2001) investigated perceptions of residents towards tourism and found that those with shorter residential tenure supported and/or worked in the tourism sector at higher levels than long-term residents. They suggested that length of residence does not necessarily "associate with perception, but is mediated by such factors as the reason for relocating to the community (such as lifestyle choice vs. employment) and the ability to adapt to tourisminduced changes within the community" (p.442). Zhang (2008) also found that there were differences in support for tourism based on individual personality factors and community segment profiles. Of interest in this study is how different stakeholders perceive the conditions for engaging in entrepreneurship. Thus, fringe community settings are unique and more research is needed to understand how the unique qualities of the various stakeholders may influence how they view factors that facilitate or prevent them from engaging in entrepreneurial activity.

Entrepreneurship in tourism. Significant scholarship has focused on the role of tourism entrepreneurship in developing and maintaining rural destinations (Bosworth and Farrell, 2011; Hall, 2005; Honggang and Shaoyin, 2014; Kline and Milburn, 2010; Koh, 2002; Koh and Hatten, 2002; Moscardo, 2014; Mottiar, 2016; Ryan et al., 2012; Wilson et al., 2001). Central to the significance of this premise is that, "the entrepreneur is the single most important player in the modern economy" (Lazear, 2005: 649). Tourism entrepreneurs can be considered the backbone for creating tourism products and a vibrant rural economy (Hall, 2005; Koh, 2002; Ryan et al., 2012), whereby supporting entrepreneurial efforts may be just as important than the role of destination management organizations themselves in creating a more competitive destination (Komppula, 2014). The broader entrepreneurship literature also notes that the environmental context-the entrepreneurial ecosystem or climate-is important to address when understanding how to foster entrepreneurs (Autio et al., 2014; Isenberg, 2011)

Entrepreneurial ecosystems can be considered "inter-connected collections of actors, institutions, social structures, and cultural values that produce entrepreneurial activity" (Roundy, 2017: 1252). That is, the framework considers the interactions of the entrepreneurs and other actors in the system, as well as the factors that enable productive entrepreneurial activity (Stam and Spigel, 2017). Isenberg (2011) noted that entrepreneurial ecosystems can be classified into six key domain areas that are important to address when fostering entrepreneurs: a culture conducive to innovation and risktaking; availability of capital and financial resources; governance and leadership that promote supportive policies; human capital to draw (including skilled labor and educational/training opportunities); a range of infrastructure, professional, and institutional support services (e.g. telecommunications, legal, accounting); and access to potential markets and distribution channels. Sometimes referred to as "innovation clusters," these ecosystems are focused on the nurturing of entrepreneurs. Largely, Isenberg's model was informed by work in large municipalities and city settings across the globe.

In tourism, researchers have identified conditions that are important for entrepreneurs in rural areas (Honggang and Shaoyin, 2014; Kline and Milburn, 2010; Kline et al., 2014b; Koh, 2002; McGehee and Kline, 2008; Wilson et al., 2001). For example, Kline and Milburn (2010) offered 10 categories of factors influencing the entrepreneurial climate of a rural community: physical infrastructure; financial infrastructure; business support services; human capital; networking opportunities and social capital; education, training and assistance; governance/leadership; community culture; quality of life (e.g. affordable housing, work-life balance); and general context (e.g. community size, proximity to urban area, tourism development stage). In comparing Isenberg (2011) and Kline and Milburn's (2010) work, we can draw many similarities across the elements identified in the models. Notable differences are the ways in which Isenberg's framework considers "venture-ready markets" (including early adopters, distribution channels, and diaspora networks), where within the tourism research, "markets" are reflected in the element of "general context" with greater concern regarding population density (and scale of the local economy), degree of rurality, and remoteness. These ideas generally reflect the concern over proximity to potential tourist markets in metro areas. In this regard, while the entrepreneurial ecosystem and e-climate frameworks can provide guidance in thinking about the factors influencing entrepreneurship in fringe communities, this paper suggests that there might be particularities to the context that need to be considered.

Entrepreneurship and relationship to community. Of interest in this paper are the unique qualities of fringe communities that may influence perceptions towards entrepreneurial conditions. Residential tenure may be a significant determinant of their perception towards 
entrepreneurial ecosystem in fringe communities. First, framed by the notion of social capital and social networks, past research has noted that established local community networks are important to the success of entrepreneurs and small businesses (Bosworth and Farrell, 2011; Kwon et al., 2013; McGehee et al., 2010). To this end, rural entrepreneurs who are more connected with their local community may be more motivated and supported by locally embedded social relations and networks. Second, the general knowledge of local context (of resources, networks, markets, etc.), is also critical in rural areas (Benneworth, 2004). Third, with consideration that newer residents may be considered amenity migrants, there is research suggesting that their motives towards entrepreneurship may be more lifestyle-oriented (Bosworth, 2009). Finally, Kline et al. (2012) found that residential tenure, as well as level of volunteerism, had the most influence over perceptions of entrepreneurial climate. Relatedly, Hallak et al. (2012) investigated the relationship between place identity and entrepreneurial self-efficacy (i.e. beliefs in their capabilities as entrepreneurs) of small and medium tourism enterprise owners, finding that place identity had a positive effect on this relationship; that is, "a tourism entrepreneur's sense of identity with the place in which his/her business operates contributes toward entrepreneurial success" (p.143). Hallak et al. (2015) found similar results in a study of Australian business owners where place identity/ sense of place with their town of resident was positively related to entrepreneurial self-efficacy.

Conversely, though, newer residents may have greater connections with other important players in the broader social and financial environments (i.e. the supply chain), and experience of business gained elsewhere (Bosworth and Farrell, 2011). As Paniagua (2002) noted in a study of urban-rural migration in Spain, new migrants to rural areas represented an entirely new socio-economic grouping to the area; after working in the city for $10+$ years, they were often at the peak of their professional careers when moving, bringing with them unmatched professional experience to their new rural surrounds. To this end, Moscardo (2014) noted that the "insider-outsider" distinction based on residential tenure was not a useful way of thinking about entrepreneurship in a rural region of Australia, finding that the most desirable tourism entrepreneur could be a long-term local or amenity migrant.

Given the lack of research that has centrally focused on entrepreneurship in fringe communities, the current research identified a need for moving beyond only residential tenure, to study differing community associations and affiliations. Specifically, this study considers residential status (i.e. resident vs. nonresident,), whether they work in the community (i.e. some individuals may live in the community but commute to other places for work, and vice versa), and residential setting (i.e. whether they live in areas within a fringe community that may be considered more "town" or "country"), as well as residential tenure (i.e. how long they have lived in the community). Understanding these variables, as well as sociodemographic variables, may provide insight as to who is more likely to emerge as entrepreneurs in the dynamic environment of fringe communities.

\section{Methods}

\section{Study area}

Moore County, consisting of 700 square miles $\left(\sim 1800 \mathrm{~km}^{2}\right)$, sits on the border between North Carolina's piedmont and coastal plain. According to the North Carolina Department of Commerce (n.d.), over 100,000 people will live in Moore County by 2019. The annual population growth rate is approximately $1.4 \%$. Around $89 \%$ of the population completed high school and about $32 \%$ have at least a bachelor's degree. The per capita income in 2014 was $\$ 27,437$. Approximately $75 \%$ of the labor force works within the county. While the majority of the population is White $(82.8 \%), 13.0 \%$ are considered African American and 6.3\% Hispanic/Latino (U.S. Census Bureau, n.d.).

It is adjacent to the Fort Bragg (U.S. Army) Military Reservation which serves as a major economic contributor to the region. Much like other nonurban areas of North Carolina that had been based on furniture, tobacco, and textiles, all three industries have faded within the last two decades, leaving fringe areas in the state in the position of having to reinvent themselves economically in a post-industrial landscape. Approximately, half the people in the county can be described as "urban" and half described as "rural." It is located an hour's drive from urban and highly populated areas; however, much of the county's land is considered rural due to population density. Aberdeen, Pinehurst, and Southern Pines, the main townships within the county, all liken themselves to having small town charm along with city amenities. It is because of this "dual identity" whereby residents view the county as both rural and urban, and neither completely either one, that makes studying the Moore County community an ideal representation of a fringe area.

Additionally, it is a fringe area where tourism is a major economic driver that has notably led to amenity migration trends in the area. Tourism expenditures in 
the county crested at $\$ 469 \mathrm{~m}$ in 2016 , a $6.1 \%$ increase from the previous year. There were 5730 people working in the tourism industry and tourism-related tax receipts in 2016 were $\$ 24 \mathrm{~m}$ for the state and nearly $\$ 13 \mathrm{~m}$ for local governments (Economic Development Partnership of North Carolina, n.d.). The tourism product primarily centers on golf-home to the internationally renowned Pinehurst Golf Course which hosted the 1999, 2005, and 2014 men's and 2014 women's U.S. Open Golf tournament-as well as equestrian activities, and historic assets (Convention \& Visitors Bureau, n.d.).

\section{Project background}

The study was initiated as a project conducted for Moore County Partners in Progress (PIP), whose goal is to increase economic development and quality of life within the county. Through gaining a better understanding of perceptions surrounding living and working in Moore County they hoped to attract and support entrepreneurs who would strengthen the local economy (Bosworth and Farrell, 2011; Paniagua, 2002). The practical industry needs of this project centered on the development of a website, informed by research, investigating the type of appealing content, message, and design for current residents, small business owners, and tourists.

Table 1. Affiliation with Moore county.

\begin{tabular}{ll}
\hline Affiliation (n=607) & $\%$ \\
\hline I currently live in Moore County & 76.8 \\
My primary home is in Moore County & 67.9 \\
I work full time or part time in Moore County & 64.4 \\
I have lived in Moore County for more than & 53.4 \\
10 years & \\
I am an active volunteer in Moore County & 28.2 \\
I lor my family and I) moved to Moore County for & 24.9 \\
$\quad$ work/professional reasons & \\
My parents live in Moore County & 23.6 \\
I have children in the K-12 school system in & 22.2 \\
$\quad$ Moore County & 19.4 \\
I am at least the second generation in my family & \\
$\quad$ to live in Moore County & 17.1 \\
I have visited Moore County for leisure/vacation & 16.8 \\
I was born in Moore County & 12.9 \\
I am a business owner in Moore County & 11.5 \\
I have visited Moore County on business & 11.2 \\
I have returned to live in Moore County after & \\
$\quad$ moving away & 11.0 \\
I have retired to Moore County & 5.1 \\
My son/daughter attends Sandhills & \\
$\quad$ Community College & \\
I have a second home or property in & Moore County
\end{tabular}

Fifteen members of the PIP Marketing Committee who represented various business sectors within the county (e.g. real estate, media, tourism, banking, retail, Chamber of Commerce, etc.), and previously established instruments in entrepreneurship and tourism literature (Kline et al., 2012; Kline et al., 2014c; Wilson et al., 2001), guided the development of the survey instrument. An American school grading scale was incorporated, asking participants to rate or "grade" various components of the county's environment $(\mathrm{A}=$ Excellent, $\mathrm{B}=$ Good, $\mathrm{C}=$ Average, $\mathrm{D}=$ Poor, and $\mathrm{F}=$ Failing).

The survey was distributed through identified community gatekeepers, membership networks affiliated with the Chamber of Commerce and the PIP Marketing Committee, who shared the survey with their membership networks as well as posted on community-based Facebook pages in order to gain access to a broad constituency. Additionally, representatives from the primary school system, the nearby military base, cultural arts organizations, young professional groups, and small business support organizations were also approached to help spread the word about the project. Survey responses were collected using an online survey platform from 7 May-10 July 2013 and yielded a total of 607 usable responses. To answer the research questions, factor analysis, $t$ tests, and analysis of variance (ANOVA) tests, or a nonparametric equivalent, were conducted to determine differences between groups; post hoc analyses were performed using the Tukey honestly significant difference (HSD) tests. Data were analyzed in Statistical Package for Social Sciences (SPSS) 22.0.

\section{Results}

\section{Descriptive results}

Respondents were provided many options that depict their association with the county and were prompted to select all that apply (Table 1). A large majority $(76.8 \%)$ were residents of the county, had a primary home in the bounty $(67.9 \%)$, worked in the county $(64.4 \%)$, and lived in the county more than ten years (53.4).

Additionally, respondents were asked other questions regarding their relationship with the county (Table 2). A majority were residents who lived in one of the towns, worked in the county, and most had lived there for more than 10 years. The average length of time that respondents have lived in Moore County is 18.2 years.

Of 581 respondents, $32.9 \%$ are male and $67.1 \%$ are female. Nearly all respondents $(93.3 \%)$ are White. Nearly half $(46.0 \%)$ are considered part of the Baby Boomer generation while one-third $(33.9 \%)$ were 
Table 2. Relationship with Moore County.

\begin{tabular}{ll}
\hline Variable & $\%$ \\
\hline Resident status $(n=607)$ & \\
$\quad$ Resident & 76.8 \\
$\quad$ Non-resident & 23.2 \\
Work in Moore County $(n=607)$ & \\
$\quad$ Yes & 64.4 \\
$\quad$ No & 35.6 \\
Residential setting $(n=205)$ & \\
$\quad$ Resident: rural & 35.6 \\
$\quad$ Resident: town & 64.4 \\
Residential tenure $(n=351)$ & \\
$\quad<5$ years & 14.2 \\
5-10 years & 27.1 \\
$11-20$ years & 23.9 \\
$21-30$ years & 16.0 \\
31 years + & 18.8 \\
\hline
\end{tabular}

members of Generation X. Respondents were asked to indicate from a provided list the classification that most accurately described their employment. Almost half $(48.6 \%)$ were employed in the public sector, followed by $29.7 \%$ who were in the private sector and/or owned their own business. A majority of respondents $(76.5 \%)$ hold a Bachelor's degree; $42.8 \%$ have an annual household income of $\$ 100,000$ or greater (Table 3). Respondents were asked to respond Absolutely, Sometimes/somewhat, or Not at all to the following statement to determine how they felt about their own entrepreneurial potential (I consider myself entrepreneurial either in my paid work or my volunteer work). the sample responded that they consider themselves to be entrepreneurial most $(35.7 \%)$ or some $(31.4 \%)$ of the time.

A host of characteristics that reflected entrepreneurial conditions and amenities were presented to the respondents. They were asked to then grade Moore County using the school grading scale. The conditions and amenities were divided into two questions - the first representing business conditions and the second social and environmental conditions. The most highly rated business elements were resident attitude toward military, resident attitude toward tourism, dependable high-speed internet, and proximity to metro area. The most highly rated social and environmental elements were golf opportunities, hospitals and medical services, attractiveness of area and natural amenities, and volunteer spirit in the communities (Tables 4 and 5). Please note the exemplary mark of an " $A$ " is scored as a 1 , while a failing grade " $F$ " is a 5 .

\section{Factor analysis}

Factor analysis was employed to reduce the number of items reflecting the conditions. The dataset was
Table 3. Socio-demographics of respondents.

\begin{tabular}{ll}
\hline Variable & $\%$ \\
\hline Generation ( $=587$ ) & \\
Greatest Generation (Born 1900-1926) & 0.0 \\
Silent Generation (Born 1927-1945) & 11.9 \\
Baby Boomer (Born 1946-1964) & 46.0 \\
Generation X (Born 1965-1980) & 33.9 \\
Generation Y/ Millennials (Born 1981-1994) & 8.0 \\
Generation Z (Born 1995-2009) & .2 \\
Employment ( $=586$ ) & \\
I own my own business & 17.4 \\
I work in the private sector & 12.3 \\
I work in the non-profit sector & 6.7 \\
I work in the public sector & 48.6 \\
I am retired & 11.1 \\
I am unemployed & 1.7 \\
Other & 2.2 \\
Education ( $n=587$ ) & \\
Some high school & 0.0 \\
High school graduate & 9.2 \\
Associate degree & 10.7 \\
Professional/trade degree & 3.6 \\
Bachelor's degree & 40.0 \\
Graduate degree & 36.5 \\
Income ( $n=479$ ) & 20.7 \\
Less than $\$ 50,000$ & 36.5 \\
\$50,001-\$100,000 & 24.8 \\
\$100,001-\$150,000 & 8.4 \\
\$150,001-\$200,000 & 9.6 \\
More than $\$ 200,000$ & \\
\hline & \\
&
\end{tabular}

determined suitable for factor analysis based sample size and inter-item correlations, Bartlett's test of sphericity (statistically significant at the .000 level) and the Kaiser-Meyer-Olkin statistic (.928 and .943, respectively) that met the recommended value of at least .6. Respondents who had "no opinion" on a condition were dropped from the analyses, thereby providing a more conservative analysis.

A principle component analysis with Varimax rotation was conducted on the 23 business conditions and 26 social and environmental conditions. The initial analysis was run without any restrictions and produced a correlations matrix, communalities, Eigenvalues, scree plot, and factor loadings. The criteria used to interpret the factor analysis were: inter-item correlation (correlation matrix), factor loadings, and operational goodness-of-fit. Communalities of the items fell within an accepted range ( $>.25$ ) with the lowest being .559 and the highest being .832 . The initial eigenvalues ranged from 1.028 to 11.837 .

The results of the initial analysis for business conditions revealed a five-factor solution, which accounted for $66.1 \%$ of the variance in the data. After reviewing the scree plot, factor loadings, 
Table 4. Business conditions/amenities.

\begin{tabular}{|c|c|c|c|c|c|c|c|c|}
\hline Element & M & A & B & $\mathrm{C}$ & $\mathrm{D}$ & $\mathrm{F}$ & NO & $n$ \\
\hline esident attitude toward military & 2.18 & 36.0 & 38.3 & 15.0 & 1.8 & .6 & 8.3 & 506 \\
\hline Resident attitude toward tourism & 2.39 & 26.0 & 39.6 & 21.7 & 3.2 & 1.4 & 8.2 & 503 \\
\hline Dependable high-speed internet & 2.68 & 19.5 & 33.7 & 25.2 & 10.5 & 3.0 & 8.1 & 507 \\
\hline Healthy economic/business environment & 2.69 & 10.2 & 43.3 & 31.0 & 6.1 & 1.6 & 7.8 & 510 \\
\hline Proximity to metro area & 2.77 & 15.2 & 30.5 & 31.3 & 13.3 & 4.8 & 5.0 & 505 \\
\hline Community size/scale of the local economy & 2.96 & 11.2 & 31.9 & 35.5 & 5.8 & 3.2 & 12.5 & 502 \\
\hline Transportation infrastructure (roads, airport, train) & 3.05 & 6.5 & 28.7 & 35.0 & 17.2 & 7.9 & 4.6 & 505 \\
\hline Business support services (printing, marketing, legal, taxes) & 3.22 & 11.1 & 33.5 & 25.5 & 5.0 & 2.0 & 23.0 & 505 \\
\hline Innovative and forward-thinking business leaders & 3.28 & 8.8 & 32.9 & 25.5 & 8.4 & 3.2 & 21.2 & 501 \\
\hline Policies to support business growth & 3.28 & 7.5 & 31.6 & 30.4 & 7.9 & 1.8 & 20.9 & 507 \\
\hline Affordable building space and land & 3.34 & 8.1 & 27.1 & 30.2 & 11.5 & 4.0 & 19.2 & 506 \\
\hline $\begin{array}{l}\text { Community is supportive and admires innovation, change, } \\
\text { risk-taking and new business }\end{array}$ & 3.34 & 8.0 & 25.4 & 31.4 & 13.4 & 3.6 & 18.2 & 500 \\
\hline Public investment in community efforts & 3.36 & 7.8 & 27.2 & 32.4 & & 2.4 & 21.7 & 503 \\
\hline Land use planning & 3.37 & 6.5 & 27.3 & 31.8 & 10.8 & 4.3 & 19.3 & 509 \\
\hline Private investment in $\mathrm{cc}$ & 3.45 & 8.8 & 25.1 & 30.9 & 8.4 & 1.8 & 25.1 & 502 \\
\hline Existing networks that welcome new members & 3.53 & 7.6 & 28.2 & 26.2 & 8.0 & 2.0 & 28.0 & 503 \\
\hline $\begin{array}{l}\text { Programs exist that publicly celebrate small businesses } \\
\text { and others' successes }\end{array}$ & 3.54 & 6.0 & 26.6 & 28.4 & 11.4 & 1.6 & 26.0 & 500 \\
\hline Labor pool skill set & 3.58 & 3.7 & 22.4 & 32.9 & 15.9 & 3.1 & 21.9 & 508 \\
\hline Innovative and forward-thinking elected officials & 3.60 & 3.6 & 20.4 & 32.3 & 17.6 & 7.8 & 18.2 & 499 \\
\hline Education and training for entrepreneurs & 3.77 & 8.0 & 20.6 & 26.4 & 9.6 & 2.2 & 33.2 & 500 \\
\hline Environment supports young adults and youth in business & 3.94 & 2.6 & 14.0 & 30.5 & 20.0 & 5.6 & 27.3 & 499 \\
\hline Mentoring programs for small business & 4.00 & 7.2 & 18.5 & 23.3 & 9.7 & 1.0 & 40.4 & 503 \\
\hline Access to start-up capital & 4.29 & 3.0 & 12.1 & 27.0 & 11.5 & 3.2 & 43.1 & 503 \\
\hline
\end{tabular}

NO: no opinion.

reliability scores, and operational fit for each set of conditions, Resident Attitude Toward Tourism and Resident Attitude Toward Military were combined with other "attitudinal components." The results of the initial analysis for social and environmental conditions also revealed a five-factor solution, accounting for $66.7 \%$ of the variance in the data. No items were dropped from either scale. Cronbach's alpha tests of reliability were conducted to assess the internal consistency of each of the subscales. The factors, their loadings, reliability scores are found in Tables 6 and 7 .

While many of the conditions were adapted from previous ecosystem literature and the survey instrument shortened, the resulting factors varied a bit from previous literature. This may be due to the variations from the original items, but may also reflect the amenities available or the perceptions of residents in Moore County. The physical infrastructure factor and the financial infrastructure factor from Kline and Milburn's study (2010), for example, appears as Capital, investment, land, labor, policies in the current study. Networking and social capital and Education, training and assistance (Kline and Milburn, 2010) became Education, mentoring, networks, business services and Innovative, supportive $\mathcal{E}$ celebratory environment. Community culture in the Kline and Milburn study aligned closely with Community spirit in the current research, and Quality of life corresponded with Community spaces/green spaces, Arts \& culture, and Diversity/options.

\section{Test results}

The purpose of this paper was to explore whether stakeholder socio-demographics and different relationships with the fringe community affects one's perception of the community's entrepreneurial ecosystem. The 49 conditions established in the literature as factors influencing entrepreneurship were reduced to nine dimensions.

\section{Relationship with county}

No statistically significant differences were found on Residential Status (respondents were a mix of residents and non-residents) or Working in County. Only one significant difference occurred between Residential Setting (where residents are considered by whether they live in the rural or urban part of the county); Basic Needs $(t=2.402, d f=102)$ was found to be significant at the $p=.018$ level. Rural residents $(n=37)$ rated the county's basic needs lower $(M=2.54$, $\mathrm{SD}=.756)$ than their town counterparts $(n=67$; 
Table 5. Social and environmental conditions/amenities.

\begin{tabular}{|c|c|c|c|c|c|c|c|c|}
\hline Element & M & A & $\mathrm{B}$ & C & D & $\mathrm{F}$ & NO & $n$ \\
\hline Golf opportunities & 1.28 & 86.3 & 8.6 & 1.9 & .2 & .4 & 2.6 & 466 \\
\hline Hospitals \& medical services & 1.75 & 53.9 & 29.6 & 10.7 & 1.7 & 1.1 & 3.0 & 469 \\
\hline Attractiveness of area and natural amenities & 1.75 & 50.2 & 33.1 & 12.3 & 1.9 & .4 & 1.9 & 462 \\
\hline Volunteer spirit in the community & 2.18 & 36.5 & 34.4 & 18.2 & 3.4 & .9 & 6.6 & 468 \\
\hline Outdoor recreation & 2.22 & 30.5 & 36.7 & 20.4 & 7.1 & 3.2 & 2.1 & 466 \\
\hline Variety of culinary options & 2.23 & 29.9 & 37.9 & 21.0 & 5.4 & 2.8 & 3.0 & 462 \\
\hline Parks and green space & 2.24 & 28.1 & 40.1 & 20.2 & 5.6 & 3.2 & 2.8 & 466 \\
\hline Faith communities & 2.26 & 28.4 & 46.2 & 14.7 & 1.3 & .4 & 9.0 & 468 \\
\hline Opportunity to buy local produce and meats & 2.29 & 28.3 & 36.2 & 24.4 & 5.4 & .9 & 4.9 & 467 \\
\hline Low crime rate/public safety & 2.29 & 24.9 & 41.3 & 23.0 & 5.6 & 1.3 & 3.9 & 465 \\
\hline Community events & 2.29 & 20.3 & 40.1 & 28.0 & 6.7 & 1.3 & 3.7 & 464 \\
\hline Sound stewardship of natural resources & 2.40 & 19.3 & 38.7 & 23.6 & 4.8 & 2.4 & 11.3 & 462 \\
\hline Resident tendency to buy and support local & 2.48 & 13.1 & 50.5 & 24.2 & 5.6 & .4 & 6.2 & 467 \\
\hline Lively downtowns and pedestrian areas & 2.58 & 17.0 & 38.5 & 25.4 & 11.6 & 3.9 & 3.7 & 465 \\
\hline Places to gather, network, visit with friends and colleague & 2.67 & 16.3 & 33.5 & 30.3 & 11.6 & 3.2 & 5.2 & 466 \\
\hline Positive, can-do, problem-solving attitudes of residents & 2.67 & 10.3 & 43.4 & 31.2 & 6.7 & .9 & 7.5 & 465 \\
\hline Performing arts & 2.70 & 14.1 & 36.3 & 31.2 & 8.1 & 4.3 & 6.0 & 468 \\
\hline Variety of shopping price points & 2.73 & 9.4 & 38.0 & 34.1 & 10.5 & 4.7 & 3.2 & 466 \\
\hline Diverse community demographics & 2.78 & 12.7 & 30.8 & 35.3 & 13.3 & 3.4 & 4.5 & 465 \\
\hline Visual arts & 2.86 & 13.2 & 31.5 & 32.6 & 10.2 & 3.7 & 8.9 & 463 \\
\hline Available, affordable health care & 2.88 & 16.1 & 32.7 & 24.7 & 9.9 & 6.2 & 10.3 & 466 \\
\hline $\begin{array}{l}\text { Effective non-governmental organizations working in } \\
\text { the community to enhance quality of life }\end{array}$ & 2.90 & 14.7 & 33.8 & 29.0 & 6.4 & .9 & 15.2 & 455 \\
\hline Available, affordable housing & 2.99 & 9.7 & 32.4 & 31.5 & 11.8 & 5.2 & 9.4 & 466 \\
\hline Options for K-12 education & 3.03 & 17.4 & 29.2 & 24.5 & 8.6 & 2.6 & 17.6 & 465 \\
\hline Ethnic restaurants & 3.28 & 9.0 & 25.5 & 35.8 & 15.0 & 7.7 & 6.9 & 466 \\
\hline Media is representative of all interests & 3.34 & 5.8 & 23.5 & 33.0 & 20.7 & 8.2 & 8.6 & 463 \\
\hline Options for childcare & 3.92 & 4.3 & 21.0 & 24.7 & 12.6 & 3.2 & 34.2 & 462 \\
\hline
\end{tabular}

NO: no opinion.

$\mathrm{M}=2.17, \mathrm{SD}=.746)$. Two significant differences were found on Residential Tenure, where respondents were categorized according to how long they've lived in the county. In both cases, the residents who had lived there more than 10 years held a more negative impression of Innovative $\mathcal{E}$ Supportive Business Environment and Basic Needs than those who had lived there 6-10 years and 1-5 years, respectively (Table 8).

\section{Socio-demographic variables}

The relationship between socio-demographic variables and perception of entrepreneurial conditions was also explored; several statistically differences were found. Across gender, women held a more positive perspective than men on four factors: Scale/Infrastructure, Community Spaces, Basic Needs, and Variety (Table 9).

The group sizes for Race were grossly unequal therefore the non-parametric Mann-Whitney test was used to measure differences between White $(n=130)$ and Non-White $(n=9)$ respondents. Significance was found at the $p<.05$ level on seven of the nine factors
Resource Investment, Scale/Infrastructure, Innovative Environment, Community Spirit, Community Spaces, Basic needs, and Arts $\mathcal{E}$ Culture. In each case, an individual identifying as White held a more positive view of these factors than Non-Whites.

Because of the uneven group sizes for employment sector, respondents who owned their own business and those who worked in private sector employment were combined, and much smaller groups such as Non-profit Sector, Retired and Students were dropped from the analysis. In doing so, it should be recognized that engagement in entrepreneurial activity can be vastly different between those who own their own a business, and those who work for a private company. In each of the three cases of statistically significant differences, the private sector rated the factors more positively than their public sector counterparts (Table 10).

In the analysis of income, the upper two categories of income were combined. Three statistically significant differences were revealed, on Community Spirit, Community Spaces, and Basic Needs factors (Table 11). 
Table 6. Business conditions factored into dimensions.

\begin{tabular}{|c|c|c|c|}
\hline & Loac & M & SD \\
\hline \multicolumn{4}{|c|}{ Capital, investment, land, labor, policies ( $\alpha=$.839) } \\
\hline Land use planning & .464 & 2.76 & .956 \\
\hline Affordable building space and land & .459 & 2.76 & 1.000 \\
\hline Labor pool skill set & .654 & 2.94 & .899 \\
\hline $\begin{array}{l}\text { Private investment in communi- } \\
\text { ty efforts }\end{array}$ & .754 & 2.64 & .895 \\
\hline $\begin{array}{l}\text { Public investment in communi- } \\
\text { ty efforts }\end{array}$ & .695 & 2.70 & .898 \\
\hline Access to start-up capital & .735 & 2.98 & .918 \\
\hline \multicolumn{4}{|l|}{$\begin{array}{l}\text { Innovative, supportive \& celebratory } \\
\text { environment }(\alpha=.865)\end{array}$} \\
\hline $\begin{array}{l}\text { Innovative and forward-thinking } \\
\text { elected officials }\end{array}$ & .745 & 3.06 & 1.000 \\
\hline $\begin{array}{l}\text { Innovative and forward-thinking } \\
\text { business leaders }\end{array}$ & .722 & 2.55 & .937 \\
\hline $\begin{array}{l}\text { Community is supportive and } \\
\text { admires innovation, change, } \\
\text { risk-taking and new business }\end{array}$ & .705 & 2.71 & .955 \\
\hline $\begin{array}{l}\text { Programs exist that publicly cele- } \\
\text { brate small businesses } \\
\text { and others' successes }\end{array}$ & .624 & 2.70 & .897 \\
\hline $\begin{array}{l}\text { Environment supports young } \\
\text { adults and youth in business }\end{array}$ & .633 & 3.17 & .920 \\
\hline Resident & .691 & 2.15 & .906 \\
\hline Resident attitude & .868 & 1.93 & .852 \\
\hline \multicolumn{4}{|l|}{$\begin{array}{l}\text { Education, mentoring, networks, } \\
\text { business services }(\alpha=\text {.881) }\end{array}$} \\
\hline $\begin{array}{l}\text { Mentoring programs for } \\
\text { small business }\end{array}$ & .773 & 2.66 & .940 \\
\hline $\begin{array}{l}\text { Existing networks that welcome } \\
\text { new members }\end{array}$ & .738 & 2.56 & .881 \\
\hline $\begin{array}{l}\text { Education and training for } \\
\text { entrepreneurs }\end{array}$ & .744 & 2.66 & .944 \\
\hline $\begin{array}{l}\text { Business support services (print- } \\
\text { ing, marketing, legal, taxes) }\end{array}$ & .538 & 2.38 & .888 \\
\hline \multicolumn{4}{|l|}{$\begin{array}{l}\text { Economic scale/health/infrastruc- } \\
\text { ture }(\alpha=.804)\end{array}$} \\
\hline $\begin{array}{l}\text { Community size/scale of the } \\
\text { local economy }\end{array}$ & .542 & 2.50 & .892 \\
\hline Proximity to metro area & .657 & 2.57 & 1.062 \\
\hline $\begin{array}{l}\text { Healthy economic/business } \\
\text { environment }\end{array}$ & .631 & 2.39 & .808 \\
\hline $\begin{array}{l}\text { Policies to support busi- } \\
\text { ness growth }\end{array}$ & .534 & 2.54 & .861 \\
\hline $\begin{array}{l}\text { Transportation infrastructure } \\
\text { (roads, airport, train) }\end{array}$ & .651 & 2.91 & 1.016 \\
\hline Dependable high-speed internet & .458 & 2.43 & 1.018 \\
\hline
\end{tabular}

SD: standard deviation.

Note: $\alpha=$ Cronbach's Alpha based on standardized items.

In each case, the two higher income groups perceived the factors more positively than the lower income groups. No statistically significant differences were found among the variables generation or education.
Table 7. Social and environmental conditions factored into dimensions.

\begin{tabular}{|c|c|c|c|}
\hline & Loadings & M & SD \\
\hline \multicolumn{4}{|c|}{ Community spaces/green spaces ( $\alpha=.869$ ) } \\
\hline Outdoor recreation & .462 & 2.13 & 1.036 \\
\hline Parks and green space & .572 & 2.12 & 1.014 \\
\hline Golf opportunities & .872 & 1.16 & .498 \\
\hline $\begin{array}{l}\text { Places to gather, network, visit } \\
\text { with friends and colleagues }\end{array}$ & .667 & 2.50 & 1.002 \\
\hline Community events & .771 & 2.25 & .895 \\
\hline $\begin{array}{l}\text { Lively downtowns and pedestri- } \\
\text { an areas }\end{array}$ & .573 & 2.45 & 1.037 \\
\hline $\begin{array}{l}\text { Attractiveness of area and natu- } \\
\text { ral amenities }\end{array}$ & .453 & 1.67 & .807 \\
\hline \multicolumn{4}{|l|}{ Arts \& culture $(\alpha=.857)$} \\
\hline Performing arts & .742 & 2.50 & .997 \\
\hline Visual arts & .787 & 2.55 & .990 \\
\hline Variety of culinary options & .605 & 2.10 & 1.000 \\
\hline Ethnic restaurants & .690 & 2.85 & 1.069 \\
\hline \multicolumn{4}{|l|}{ Basic community needs ( $\alpha=.795)$} \\
\hline Hospitals \& medical services & .488 & 1.61 & .852 \\
\hline Available, affordable housing & .725 & 2.67 & 1.020 \\
\hline Available, affordable health care & .780 & 2.53 & 1.116 \\
\hline Low crime rate/public safety & .698 & 2.14 & .931 \\
\hline \multicolumn{4}{|l|}{ Community spirit $(\alpha=.856)$} \\
\hline $\begin{array}{l}\text { Effective non-governmental } \\
\text { organizations working in the } \\
\text { community to enhance quality } \\
\text { of life }\end{array}$ & .739 & 2.33 & .875 \\
\hline $\begin{array}{l}\text { Resident tendency to buy and } \\
\text { support local }\end{array}$ & .718 & 2.24 & .778 \\
\hline $\begin{array}{l}\text { Positive, can-do, problem-solving } \\
\text { attitudes of residents }\end{array}$ & .676 & 2.38 & .810 \\
\hline $\begin{array}{l}\text { Media is representative of } \\
\text { all interests }\end{array}$ & .656 & 2.97 & 1.035 \\
\hline $\begin{array}{l}\text { Opportunity to buy local produce } \\
\text { and meats }\end{array}$ & .577 & 2.09 & .904 \\
\hline Volunteer spirit in the community & .666 & 1.89 & .911 \\
\hline $\begin{array}{l}\text { Sound stewardship of natu- } \\
\text { ral resources }\end{array}$ & .489 & 2.25 & .940 \\
\hline \multicolumn{4}{|l|}{ Diversity/options ( $\alpha=.801)$} \\
\hline Diverse community demographics & .491 & 2.60 & .976 \\
\hline Faith communities & .626 & 1.92 & .776 \\
\hline Variety of shopping price points & .500 & 2.62 & .944 \\
\hline Options for childcare & .533 & 2.82 & .972 \\
\hline Options for $\mathrm{K}-12$ education & .568 & 2.36 & 1.013 \\
\hline
\end{tabular}

SD: standard deviation.

Note: $\alpha=$ Cronbach's Alpha based on standardized items.

\section{Entrepreneurial self-rating}

Respondents were asked to rate themselves in their paid or volunteer work as to whether they are entrepreneurial. The entrepreneurially minded felt more positive about the county's Networks than the other two groups, but were more critical regarding the county's Variety (Table 12). 
Table 8. Ratings of ecosystem factors by residential tenure.

\begin{tabular}{llllllll}
\hline Item & df & F & Sig. & $\begin{array}{l}1-5 \text { years } \\
\text { (M, SD) }\end{array}$ & $\begin{array}{l}6-10 \text { years } \\
\text { (M, SD) }\end{array}$ & $\begin{array}{l}11-20 \text { years } \\
\text { (M, SD) }\end{array}$ & $\begin{array}{l}\text { Over 20 years } \\
\text { (M, SD) }\end{array}$ \\
\hline $\begin{array}{l}\text { Innovative \& supportive } \\
\text { business environment }\end{array}$ & $3,39.265^{\mathrm{b}}$ & 2.989 & .043 & $\begin{array}{l}n=14^{\mathrm{a}} \\
2.34(.708)\end{array}$ & $\begin{array}{l}18 \\
2.45(.455)\end{array}$ & $22.83(.488)$ & $2.68(.681)$ \\
\begin{tabular}{l} 
Basic needs \\
\hline
\end{tabular} & 3,100 & 3.327 & .023 & $1.88(.553)$ & $2.11(.676)$ & $2.15(.797)$ & $2.49(.753)$ \\
\hline
\end{tabular}

SD: standard deviation.

Note: A higher mean indicates a more negative perspective.

${ }^{a} n$ values are lower due to listwise deletion of missing data.

${ }^{\mathrm{b}} p<0.05$; Equal variances not assumed; Welch test statistic used.

Table 9. Ratings of ecosystem factors by gender.

\begin{tabular}{llllll}
\hline Item & $\mathrm{df}$ & $\mathrm{t}$ & $\mathrm{Sig}$ & Men M(SD) & Women M(SD) \\
\hline & & & & $n=52$ & 84 \\
Scale/infrastructure & 130.036 & -1.197 & .057 & $3.14(1.226)$ & $2.63(1.280)$ \\
Community spaces $^{\mathrm{a}}$ & 132.011 & -2.035 & .029 & $3.08(1.141)$ & $2.51(1.165)$ \\
Basic needs $^{\mathrm{a}}$ & 129.956 & -5.030 & .000 & $4.50(.662)$ & $4.08(1.036)$ \\
Diversity/options & 134 & -2.621 & .028 & $3.14(1.379)$ & $2.41(1.322)$ \\
\hline
\end{tabular}

SD: standard deviation.

${ }^{a} p<0.05$; Equal variances not assumed.

Table 10. Ratings of ecosystem factors by employment sector.

\begin{tabular}{llllll}
\hline Item & $\mathrm{df}$ & $\mathrm{t}$ & $\mathrm{Sig}$ & Private M(SD) & Public M(SD) \\
\hline & & & & $n=46$ & 72 \\
Community spirit & 116 & -1.794 & .075 & $2.26(.658)$ & $2.49(.654)$ \\
Community spaces & 116 & -2.653 & .009 & $1.92(.646)$ & $2.57(.679)$ \\
Basic needs & 116 & -2.401 & .018 & $2.13(.783)$ & $2.48(.761)$ \\
\hline
\end{tabular}

SD: standard deviation. $p<0.05$.

Table 11. Ratings of ecosystem factors by income.

\begin{tabular}{|c|c|c|c|c|c|c|c|}
\hline Item & $\mathrm{df}$ & $\mathrm{F}$ & Sig. & $\begin{array}{l}<\$ 50 K \\
(M, S D)\end{array}$ & $\begin{array}{l}\$ 50-100 K \\
(M, S D)\end{array}$ & $\begin{array}{l}\text { \$100-150K } \\
\text { (M, SD) }\end{array}$ & $\begin{array}{l}>\$ 150 K \\
(M, S D)\end{array}$ \\
\hline & & & & $n=28$ & 50 & 24 & 20 \\
\hline Resource investment & 3,118 & 2.750 & .046 & $2.86(.688)$ & $2.97(.813)$ & $2.51(.675)$ & $2.60(.661)$ \\
\hline Scale/infrastructure & 3,118 & 2.189 & .093 & $2.59(.786)$ & $2.72(.732)$ & $2.43(.594)$ & $2.28(.570)$ \\
\hline Innovative environment & $3,54.438$ & 2.702 & 0.54 & $2.76(.865)$ & $2.76(.646)$ & $2.35(.619)$ & $2.51(.523)$ \\
\hline Community Spirit ${ }^{a}$ & $3,56.890$ & 3.217 & .029 & $2.45(.805)$ & $2.59(.690)$ & $2.21(.629)$ & $2.20(.423)$ \\
\hline Community Spaces $^{a}$ & 3. 57.248 & 8.100 & .000 & $2.16(.767)$ & $2.39(.705)$ & $1.99(.730)$ & $1.75(.376)$ \\
\hline Basic needs ${ }^{a}$ & $3,58.903$ & 18.241 & .000 & $2.57(.816)$ & $2.6(.832)$ & $2.02(.667)$ & $1.675(.381)$ \\
\hline
\end{tabular}

SD: standard deviation.

${ }^{a} p<0.05$; Equal variances not assumed; Welch test statistic used in place of $F$.

\section{Discussion}

This study moves the conversation forward regarding conditions of entrepreneurial ecosystem/climate in fringe communities. With an explicit acknowledgement that these communities hold unique characteristics and are affected by diverse stakeholders and their differing associations with community, this study's authors sought to understand how association with sociodemographic and community relationship factors 
Table 12. Ratings of ecosystem factors by entrepreneurial self-rating.

\begin{tabular}{|c|c|c|c|c|c|c|}
\hline Item & $d f$ & $\mathrm{~F}$ & Sig. & Yes (M, SD) & $\begin{array}{l}\text { Somewhat/it } \\
\text { depends (M, SD) }\end{array}$ & No $(M, S D)$ \\
\hline & & & & $n=57$ & 46 & 36 \\
\hline Networks ${ }^{a}$ & $2,83.508$ & 2.666 & .075 & $2.39(.885)$ & $2.71(.635)$ & $2.71(.803)$ \\
\hline Variety & 2,136 & 2.721 & .069 & $2.65(.586)$ & $2.54(.717)$ & $2.49(.706)$ \\
\hline
\end{tabular}

SD: standard deviation.

${ }^{a}$ Equal variances not assumed; Welch test statistic used in place of $\mathrm{F}$.

Table 13. Statistically significant findings with the group who held the lower, more negative opinion of that particular factor identified.

\begin{tabular}{|c|c|c|c|c|c|c|}
\hline & $\begin{array}{l}\text { Residential } \\
\text { setting }\end{array}$ & $\begin{array}{l}\text { Residential } \\
\text { tenure }\end{array}$ & Gender & Race & Employment & Income \\
\hline $\begin{array}{l}\text { Capital, investment, land, } \\
\text { labor, policies }\end{array}$ & & & & Non-whites & & $\begin{array}{l}\text { Lower } \\
\quad \text { income }\end{array}$ \\
\hline $\begin{array}{l}\text { Innovative, supportive \& } \\
\text { celebratory environment }\end{array}$ & & $\begin{array}{l}\text { Long-time } \\
\text { residents }\end{array}$ & & Non-whites & & $\begin{array}{l}\text { Lower } \\
\quad \text { income }\end{array}$ \\
\hline \multicolumn{7}{|l|}{$\begin{array}{l}\text { Education, mentoring, networks, } \\
\text { business services }\end{array}$} \\
\hline $\begin{array}{l}\text { Economic scale/health/ } \\
\text { infrastructure }\end{array}$ & & & Males & Non-whites & & $\begin{array}{l}\text { Lower } \\
\quad \text { income }\end{array}$ \\
\hline Community spaces/green spaces & & & Males & Non-whites & $\begin{array}{r}\text { Public sector } \\
\text { employees }\end{array}$ & $\begin{array}{l}\text { Lower } \\
\quad \text { income }\end{array}$ \\
\hline Arts \& culture & & & & Non-whites & & \\
\hline Basic community needs & $\begin{array}{l}\text { Rural } \\
\quad \text { residents }\end{array}$ & $\begin{array}{l}\text { Long-time } \\
\text { residents }\end{array}$ & Males & Non-whites & $\begin{array}{r}\text { Public sector } \\
\text { employees }\end{array}$ & $\begin{array}{l}\text { Lower } \\
\quad \text { income }\end{array}$ \\
\hline Community spirit & & & & Non-whites & $\begin{array}{r}\text { Public sector } \\
\text { employees }\end{array}$ & $\begin{array}{l}\text { Lower } \\
\quad \text { income }\end{array}$ \\
\hline Diversity/options & & & Males & & & \\
\hline
\end{tabular}

played into perceptions toward entrepreneurial climate. That is, this study investigated perceptions across stakeholders of how well the community is performing with regard to the factors that foster entrepreneurship. Overall, the findings found significant differences in certain groupings of stakeholders. Table 13 summarizes these differences and identifies the groups who held lower, more negative opinions of certain entrepreneurial conditions in Moore County.

This study demonstrated that community relationships are more complex and the nature of that relationship is not singularly dependent on residential tenure. While tenure certainly drew out differences (i.e. long-term residents had a more negative outlook towards some conditions influencing entrepreneurial capacity), residential setting also showed differences where residents that lived in the rural areas of the county had a more negative perception of basic community needs. It is also important to note that the findings of this study had some inconsistencies with previous literature. Dissimilar to Kline et al. (2012), the long-term residents in the current study had a more negative impression of the entrepreneurial ecosystem dimensions that held a statistical difference (basic community needs and innovative, supportive \& celebratory environment). Within the Kline et al.'s study, the long-term residents expressed contentment with the ecosystem. This finding could be explained by the idea that long-term residents may be more rooted in place and less likely to "pick up and move" to new places even if they may have a more conducive entrepreneurial environment (see Kline et al., 2012; Reuschke, 2014). In other words, it is possible that they have been more jaded by entrepreneurial conditions but willing to stick it out because of their connection to the community.

Additionally, this study found that public service sector employees and men tended to have a more negative subjective view of the entrepreneurial climate. This may be explained by public sector employees having a better grasp on community assets and deficits, or could represent a stark difference of the importance 
of entrepreneurship in the private vs. the public sector. This study also demonstrated that lines of race and income are the most significant in terms of explaining perceptions towards the conditions contributing to the entrepreneurial ecosystem in fringe communities. Individuals identifying as non-White had a more negative view towards the entrepreneurial ecosystem.

However, it is also worth noting the elements of the analysis that did not vary in any statistically significant way. For example, no statistically significant differences were found among the variables generation or education. This is good news since Moore County is hoping to attract more Millennial age professionals to the county. However, it should still be noted that Millennials that may also be considered part of the creative class are being drawn towards cities compared to fringe communities (Walker, 2017)—an issue beyond the scope of this study.

The ecosystem dimension related to Education, mentoring, networks, business services did not vary across any independent variables, and Arts $\mathcal{E}$ culture and Diversity/ options each varied across only one. All three dimensions held relatively moderate favor among most residents-averaging around a "B-" on the grading scale or an approximate mean of 2.5 . While this rating could be higher, two of these dimensions in particular relate to the factors identified by Wilson et al. (2001). A complete tourism package was one of the necessary features for successful rural tourism development. Arts and culture, and the shopping item within Diversity/options for that matter, directly relate to an area's tourism package. Our dimension of Education, mentoring, networks, business services directly relates to three of Wilson et al. factors: coordination and cooperation between businesspersons and local leadership, coordination and cooperation between rural tourism entrepreneurs, and information and technical assistance for tourism development and promotion. Likewise, many other studies have cited the need for networking opportunities to build social capital for tourism development (Kline et al., 2014b; Kwon et al., 2013; McGehee et al., 2010). Over twothirds $(67.1 \%)$ of respondents considered themselves absolutely or somewhat entrepreneurial. This statistic is likely more useful to community leaders than the test results, whereby respondents who self-rated themselves as entrepreneurially minded perceived the diversity/ option more negatively than their counterparts; however, the difference in means was slight. Overall, each of the entrepreneurial self-rating groups rated the community conditions to as slightly below average.

\section{Implications}

It is vital that fringe communities build the infrastructure that is favorable to the incubation of entrepreneurship while being mindful of the different needs of stakeholders. Fringe communities are made up of distinctly different residents who reflect diverse origins, backgrounds, and values, but who must make future community planning decisions together. To this end, tourism entrepreneurs are often leaders in development efforts (e.g. Komppula, 2014; Moscardo, 2014) and play a significant role in shaping and reshaping the identity of the community.

Researchers are increasingly acknowledging that power dynamics are an important issue in community and tourism planning in the wake of changing rural areas (Cloke, 2006; Frisvoll, 2012; Halfacree, 2004). Equally, understanding what contributes to the success of entrepreneurs has been important questions in the broader literature (e.g. Acs et al., 2009; Poschke, 2013), and this question was considered within the context of fringe communities where unique dynamics that may promote entrepreneurship across the diverse stakeholder groups must be considered. Though no two communities or contexts are the same, this study has demonstrated that differences towards entrepreneurial ecosystem conditions exist in fringe communities. It raises questions related to perception of opportunities for entrepreneurship, particularly among groups that perceived some conditions that support entrepreneurship were weaker than others. Why did some groups perceive weaker performance than others? How can those differences be addressed to assure equitable access to opportunity in tourism entrepreneurship?

It is important for community leaders to understand the different perceptions toward these conditions so that they might adjust the marketing (and hence, awareness) of community amenities and programs or initiate new amenities and programs altogether that would target the different socio-demographic and community groups. In the particular case of Moore County, there is a need for further research to understand why the different groups perceived the entrepreneurial ecosystem in a certain way in order to craft environments that proactively encourage the creation of programs, initiatives, businesses, and organizations that contribute to the social, environmental, and economic vitality of a place.

Overall, this study has furthered the entrepreneurial ecosystem literature within the context of fringe communities and as it relates to tourism development. Great care was taken to include a diverse range of community organizations, however, because the sample was procured from gatekeeper organizations (e.g. PIP and the Chamber of Commerce), the limitations of convenience sampling should be recognized. That is, as established economic development organizations, these organizations are engaged with stakeholders 
who are more active in development efforts, and those who are "connected" within these networks via social media. Additionally, respondents who had "no opinion" on a condition were dropped from the analyses providing a more conservative analysis. Thus, missing data was dropped from the analysis list wise which resulted in a smaller sample for testing, however, a more rigorous result. Future studies building on this research should expand into different types and sizes of fringe communities.

\section{Conclusions}

Entrepreneurial climate has almost exclusively explored either rural or urban contexts leaving a need to better understand communities located in between that are not categorically rural or urban (Champion and Hugo, 2004; Chase, 2015; Taylor, 2011). These fringe communities that are situated in the continuum of peri-urbanization are increasingly having to negotiate the complexities of transitioning natural, built, economic, political, social, and cultural landscapes. Community and tourism planning must address the challenges that this presents, including conflict over land use and physical changes to the natural resources that have attracted many of the amenity migrants and other new residents in the first place (Chase, 2015). As well, planners must be increasingly cognizant of the pressures to community identity and sense of place as diverse perspectives of new stakeholders may breakdown what had traditionally been perceived as more harmonized practices when everyone historically drew from the same background, history, and shared set of values. As such, entrepreneurs are often some of the most significant change agents in development, which is why attention needs to be paid to who become tourism entrepreneurs in fringe communities. To that end, tourism plays a significant role in these contexts as it often has the potential to become a major industry because of the amenities and resources that so often exist in fringe communities that attract people to visit. Likewise, tourism is an industry that is known for its ability to create entrepreneurial opportunities for the diverse residents living in fringe communities.

\section{Declaration of conflicting interests}

The author(s) declared no potential conflicts of interest with respect to the research, authorship, and/or publication of this article.

\section{Funding}

The author(s) received no financial support for the research, authorship, and/or publication of this article.

\section{References}

Acs ZJ, Braunerhjelm P, Audretsch DB, et al. (2009) The knowledge spillover theory of entrepreneurship. Small Business Economics 32(1): 15-30.

Autio E, Kenney M, Mustar P, et al. (2014) Entrepreneurial innovation: The importance of context. Research Policy 43(7): 1097-1108.

Benneworth P (2004) In what sense "regional development?": Entrepreneurship, underdevelopment and strong tradition in the periphery. Entrepreneurship $\mathcal{E}$ Regional Development 16(6): 439-458.

Bosworth G (2009) Education, mobility and rural business development. Fournal of Small Business and Enterprise Development 16(4): 660-677.

Bosworth G and Farrell H (2011) Tourism entrepreneurs in Northumberland. Annals of Tourism Research 38: 1474-1494.

Butt A and Fish B (2016) Amenity, landscape and forms of peri-urbanization around Melbourne, Australia. In: Kennedy ML, Butt A and Amati M (eds) Conflict and Change in Australia's Peri-Urban Landscapes. New York: Routledge, pp.7-27.

Champion $\mathrm{T}$ and Hugo G (2004) New Forms of Urbanization: Beyond the Urban-Rural Dichotomy. Aldershot, UK: Ashgate Publishing Ltd.

Chase J (2015) Bending the rules in the foothills-County general planning in exurban Northern California. Society E Natural Resources 28(8): 857-872.

Cloke P (2006) Conceptualizing rurality. In: Cloke P, Marsden $\mathrm{T}$ and Mooney PH (eds) Handbook of Rural Studies. London: Sage Publications, pp.18-28.

Convention \& Visitors Bureau Pinehurst, Southern Pines, Aberdeen Area of North Carolina (n.d) 2014 U.S. Open Championships. Available at: www.homeofgolf. com/play-golf/2014-us-open (accessed 30 January 2017).

Economic Development Partnership of North Carolina (n.d) Travel economic impact model. Available at: http://partners.visitnc.com/research-3/economic-impact/ teim.html (accessed 30 November (2017).

Freire-Gibb LC and Nielsen K (2014) Entrepreneurship within urban and rural areas: Creative people and social networks. Regional Studies 48(1): 139-153.

Frisvoll S (2012) Power in the production of spaces transformed by rural tourism. Fournal of Rural Studies 28(4): 447-457.

Gosnell H and Abrams J (2009) Amenity migration: Diverse conceptualizing of drivers, socioeconomic dimensions, and emerging challenges. Geofournal 76(4): 303-322.

Halfacree K (2004) Rethinking 'rurality'. In: Champion T and Hugo G (eds) New Forms of Urbanization: Beyond the Urban-Rural Dichotomy. Burlington, VT: Ashgate Publishing Limited, pp.285-304.

Halfacree K (2012) Heterolocal identities? Counter-urbanisation, second homes, and rural consumption in the era of mobilities. Population, Space and Place 18(2): 209-224.

Hall CM (2005) Rural wine and food tourism cluster and network development. In: Hall D, Kirkpatrick I and Mitchell M (eds) Rural Tourism and Sustainable Business. Tonawanda, NY: Channel View Publications, pp.149-164. 
Hallak R, Assaker G and Lee C (2015) Tourism entrepreneurship performance: The effects of place identity, self-efficacy, and gender. Fournal of Travel Research 54(1): 36-51.

Hallak R, Brown G and Lindsay N (2012) The place identity-performance relationship among tourism entrepreneurs: A structural equation modeling analysis. Tourism Management 33: 143-154.

Honggang X and Shaoyin M (2014) Regional environment of destination and the entrepreneurship of small tourism businesses: A case study of Dali and Lijiang of Yunnan Province. Asia Pacific Fournal of Tourism Research 19(2): 144-161.

Isenberg D (2011) The entrepreneurship ecosystem strategy as a new paradigm for economic policy: Principles for cultivating entrepreneurship. Presentation at the Institute of International European Affairs, 12 May, Dublin, Ireland.

Kline C, McGehee N, Paterson S, et al. (2012) Using ecological systems theory and density of acquaintance to explore resident perception of entrepreneurial climate. Fournal of Travel Research 52(3): 294-309.

Kline C and Milburn LA (2010) Ten categories of entrepreneurial climate to encourage rural tourism development. Annals of Leisure Research 13(1-2): 320-348.

Kline C, Shah N and Rubright H (2014b) Applying the positive theory of social entrepreneurship to understand food entrepreneurs and their operations. Tourism Planning E Development 11(3): 330-342.

Kline C, Shah NM, Tsao J, et al. (2014c) Support and challenge factors for tourism entrepreneurs: Two cases from North Carolina, USA. Anatolia: An International fournal of Tourism and Hospitality Research 25(3): 479-482.

Koh KY (2002) Explaining a community touristscape: An entrepreneurism model. International fournal of Hospitality and Tourism Administration 3(2): 21-48.

Koh KY and Hatten TS (2002) The tourism entrepreneur: The overlooked player in tourism development studies. International Fournal of Hospitality \& Tourism Administration 3(1): 21-48.

Komppula R (2014) The role of individual entrepreneurs in the development of competitiveness for a rural tourism destination - A case study. Tourism Management 40: 361-371.

Koster R, Lemelin RH and Agnew K (2010) Frolicking in the fringe: An assessment of the state of exurban tourism in Canada. In: Beesly KB (ed) Rural-Urban Fringe in Canada: Conflict and Controversy, Manitoba: Rural Development Institute. Manitoba Canada: Rural Development Institute, Brandon University, pp.144-157.

Kwon SW, Heflin C and Ruef M (2013) Community social capital and entrepreneurship. American Sociological Review 78(6): 980-1008.

Lazear EP (2005) Entrepreneurship. Fournal of Labor Economics 23(4): 649-680.

McGehee NG, Lee S, O'Bannon TL, et al. (2010) Tourismrelated social capital and its relationship with other forms of capital: An exploratory study. Fournal of Travel Research 49(4): 486-500.

McGehee NG and Kline CS (2008) Entrepreneurship and the Rural Tourism Industry: A Primer. In Moscardo G (ed) Building Community Capacity for Tourism Development. United Kingdom: CABI Publishing, p.38.
Mottiar Z (2016) The importance of local area as a motivation for cooperation among rural tourism entrepreneurs. Tourism Planning E Development 13(2): 203-218.

Moore County Partners in Progress (n.d) Demographics. Available at: www.moorebusiness.org/demographics/ (accessed 1 December 2017).

Moscardo G (2014) Tourism and community leadership in rural regions: Linking mobility, entrepreneurship, tourism development and community well-being. Tourism Planning \& Development 11(3): 354-370.

North Carolina Department of Commerce (n.d) ACCESSNC: State, region and county profiles. Available at: http:// accessnc.commerce.state.nc.us/docs/countyProfile/NC/ 37125.pdf (accessed 1 December 2017).

Paniagua A (2002) Urban-rural migration, tourism entrepreneurs and rural restructuring in Spain. Tourism Geographies 4(4): 349-371.

Pavelka J and Draper D (2015) Leisure negotiation within amenity migration. Annals of Tourism Research 50: 128-142.

Poschke M (2013) Who becomes an entrepreneur? Labor market prospects and occupational choice. Fournal of Economic Dynamics and Control 37(3): 693-710.

Reuschke D (2014) Self-employment, internal migration and place embeddedness. Population, Space and Place 20(3): 235-249.

Roundy PT (2017) Social entrepreneurship and entrepreneurial ecosystems: Complementary or disjoint phenomena? International fournal of Social Economics 44(9): 1252-1267.

Ryan T, Mottiar Z and Quinn B (2012) The dynamic role of entrepreneurs in destination development. Tourism Planning \& Development 9(2): 119-131.

Stam E and Spigel B (2017) Entrepreneurial ecosystems. In: Blackburn R, De Clercq D, Heinonen J, et al. (eds) Handbook for Entrepreneurship and Small Business. London: SAGE.

Taylor L (2011) No boundaries: Exurbia and the study of contemporary urban dispersion. Geofournal 76(4): 323-339.

Timothy DJ (2005) Rural tourism business: A North American overview. In: Hall D, Kirkpatrick I and Mitchell M (eds) Rural Tourism and Sustainable Business. Tonawanda, NY: Channel View Publications, pp.41-62.

U.S. Census Bureau and Department of Commerce (n.d) State \& county quickfacts. Available at: http:/quickfacts. census.gov/qfd/states/37/37125.html (accessed 1 December 2017).

Walker KE (2017) The shifting destinations of metropolitan migrants in the US, 2005-2011. Growth and Change: $A$ Fournal of Urban and Regional Policy 48: 532-551.

Walker P and Fortmann L (2003) Whose landscape? A political ecology of the "exurban" Sierra. Cultural Geographies 10(4): 469-491.

Weaver DB (2005) The distinctive dynamics of exurban tourism. International fournal of Tourism Research 7(1): 23-33.

Weaver DB and Lawton LJ (2001) Resident perceptions in the urban-rural fringe. Annals of Tourism Research 28(2): 439-458.

Weaver DB and Lawton LJ (2004) Visitor attitudes toward tourism development and product integration in an 
Australian urban-rural fringe. Fournal of Travel Research 42(3): 286-296.

Weaver DB and Lawton LJ (2008) Perceptions of a nearby exurban protected area in South Carolina, United States. Environmental Management 41(3): 389-397.

Wilson S, Fesenmaier DR, Fesenmaier J, et al. (2001) Factors for success in rural tourism development. Fournal of Travel Research 40(2): 132-138.

Zhang J (2008) Understanding host community attitudes towards tourism and resident-tourist interaction: A sociobehavioural study of Melbourne's urban-rural fringe. Doctoral Dissertation, RMIT University, Melbourne.

\section{Author Biographies}

Carol Kline is an Associate Professor of Hospitality and Tourism Management at Appalachian State University in the Department of Management. Her research interests focus broadly on tourism planning and development and tourism sustainability but cover a range of topics such as foodie segmentation, craft beverages, agritourism, wildlife tourism, animal welfare in tourism, tourism entrepreneurship, niche tourism markets, and tourism impacts to communities.
Lauren Duffy is an Assistant Professor in the Department of Department of Parks, Recreation, and Tourism Management at Clemson University. Her research interests are in tourism planning and development with a particular focus on how power dynamics influence stakeholder participation throughout the tourism planning process, and how if effects the distribution of tourism impacts and resources as a result of tourism development.

Dana Clark is a Professor and Program Director for the Hospitality and Tourism Management Program in the Department of Management at the John A. Walker College of Business at Appalachian State University in Boone, North Carolina. Clark holds a BA and MBA from the University of Georgia and a Ph.D. from the Virginia Polytechnic Institute and State University. He has worked on dozens of consulting projects. 